\title{
Biohydrogen Production in Substrates Combination of Vinasse and Tofu Whey Using Photosynthetic Bacteria Rhodobium marinum
}

\author{
Nusaibah $^{\mathrm{a}}$, Khaswar Syamsu ${ }^{\mathrm{b}}$, Dwi Susilaningsih ${ }^{\mathrm{c}}$ \\ ${ }^{a}$ Department of Marine Processing Product, Polytechnic of Marine and Fisheries Pangandaran, Pangandaran 46396, Indonesia \\ E-mail: nunus.hokudai@gmail.com \\ ${ }^{b}$ Department of Biotechnology, Postgraduate School Bogor Agricultural University, Bogor 16680, Indonesia \\ E-mail:khaswars@yahoo.com
}

${ }^{c}$ Laboratory of Bioenergy and Bioprocess, Indonesia Institute of Science, Bogor 16911, Indonesia

E-mail: dwi.susilaningsih@yahoo.sg

\begin{abstract}
Hydrogen gas is generated by the fossil fuel refinery process, fixation of sunlight, wind turbine, and water electrolysis. Hydrogen gas is promising energy due to its high energy content and clean combustion. It is also able to be produced by fermentation series, using waste as a substrate. Vinasse is a waste of ethanol distillation from fermented molasses, which still has high Chemical Oxygen Demand (COD) content. The COD is mainly composed of many organic loads that potential to produce hydrogen. Tofu whey (TW), which still has high nitrogen content, is waste generated from the tofu production process. TW is reported to contain high of valuable nutrients, including protein that contains nitrogen. The combination of both liquid wastes is a suitable substrate for hydrogen gas production using Rhodobium marinum. This work aimed to study hydrogen gas, Hydrogen Production Rate, and COD Removal Rate of hydrogen production using a combination of both liquid wastes. Biohydrogen production was examined by varying COD of vinasse/Nitrogen from TW $(10,000 / 1-50,000 / 1)$ at a particular fermentation time in the $3^{\text {rd }}, 6^{\text {th, }}$ and $9^{\text {th }}$ days. The highest hydrogen gas and Hydrogen Production Rate (HPR) was obtained at substrate concentration 40,000/1 on $9^{\text {th }}$ day of fermentation, namely $95.72 \pm 6.51 \mathrm{~mL} \mathrm{H}_{2} / \mathrm{L}$ and $121.44 \mathrm{~mL} \mathrm{H}_{2} / \mathrm{L} / \mathrm{d}$, respectively. COD removal and COD Removal Rate were $7820 \pm 400.69 \mathrm{mg}$ $\mathrm{COD} / \mathrm{L}$ and $799.77 \mathrm{mg} \mathrm{COD} / \mathrm{L} / \mathrm{d}$. Thus, it can be concluded that the combination of Vinasse and TW has potential as a substrate to biohydrogen production using Rhodobium marinum.
\end{abstract}

Keywords — biohydrogen; vinasse; tofu whey; R. marinum.

\section{INTRODUCTION}

Hydrogen gas is clean energy that can be generated from various sources such as fixation of sunlight, wind turbines, water electrolysis, marine turbines, and biological processes (fermentation). The ease of making the hydrogen gas makes it possible to make career energy in the area having specific sources (regions that are isolated or on a desert island). The process of making and burning hydrogen gas does not produce substances harmful to the environment. Currently, $96 \%$ of hydrogen gas is produced from fossil fuels, with $48 \%$ from natural gas, $30 \%$ of hydrogen carbons, $18 \%$ from coal, $4 \%$ of electrolysis, and $1 \%$ is produced by biomass. There are some hydrogen gas production methods, such as steam reforming, water electrolysis, gasification, and biological (fermentation). Steam reforming is the process of high temperatures water vapor that will separate hydrogen from carbon atom bonds in methane. This method still uses fossil fuels for the manufacturing process and for producing heat sources. The second method, electrolysis, also requires enormous electrical energy derived from fossil fuels. The third method, gasification, uses biomass as a base material, but the hydrogen production process still requires very high temperatures. These three methods above are considered less efficient in terms of cost (uneconomical), the necessary amount of energy, and the energy produced is not renewable. Biohydrogen gas production requires raw materials or substrates that support the growth of microorganisms producing hydrogen gas. The main criterion for selection substrate is availability producing biohydrogen gas, pricing, carbon, nitrogen, organic compounds, and naturally degrade [1]. Biological hydrogen production is known to have a more effective and efficient process. It can be done by several methods, including dark fermentation, photo fermentation, direct photolysis, indirect photolysis [2]. Autotrophic and heterotrophic microorganisms can produce biohydrogen. In autotrophic conversion or better known as direct and indirect 
biophotolysis, solar energy is directly converted into hydrogen through photosynthetic reactions mediated by photosynthetic microorganisms includes microalgae, Protista, and photosynthetic bacteria. Whereas in heterotrophic conditions, organic substrates are converted into simpler organic components simultaneously and produce molecular hydrogen. There are two types of heterotrophic conversion, namely photo fermentation carried out by photosynthetic bacteria, and dark fermentation carried out by anaerobic bacteria that convert carbohydrates into biohydrogen [3]. Economically, to produce hydrogen gas can be done by using organic waste materials as substrates for producing biohydrogen, for example, urban waste, and agricultural waste, solid and liquid waste from the organic industry [4]. Various biomass and renewable substrates are considered suitable substrate for biohydrogen production due to their high organic richness, less nutrient need, and positive net energy production. In particular, industrial wastewaters are abundantly available substrates, and they are categorized as low-cost and extensively obtainable biodegradable substrates[5,6,7]. Using waste as a substrate than others is economical, and it can reduce the accumulation of waste in the environment. Some examples of potential waste to produce biohydrogen is vinasse and tofu whey.

Vinasse is the residue of distillation ethanol production using molasses. Molasses from the sugar industry is processed to produce ethanol. The residual fluid after the ethanol extraction is known as vinasse. In the ethanol industry, the production of $1 \mathrm{~L}$ of ethanol will produce 8-15 $\mathrm{L}$ of vinasse. Vinasse contains organic material (COD) very high at more than 100,000 $\mathrm{mg} / \mathrm{L}$ [8] and BOD (biochemical oxygen demand) around 35-50 $\mathrm{g} \mathrm{O}_{2} / \mathrm{L}$ [9]. In general, vinasse is acidic, has a low $\mathrm{pH}$, colored dark brown almost black, and the content of organic and inorganic components is very high [10]. The amount of vinasse is abundant in this world. The distillation process of molasses 110,000-120,000 tons can produce vinasse 70,000 tons per year [11]. Vinasse contains very high organic components, and the amount in the world is abundant to pollute the environment. However, on the other hand, by doing pretreatment before, a high organic component and a lot of macro and micronutrients from vinasse can be one of the raw materials for an alternative energy source for biohydrogen production.

Tofu Whey (TW) that is used in this study is the remaining liquid waste from the clotting process (coagulation) of tofu. Nowadays, TW is used as animal feed, fertilizer or simply, discarded; its disposal represents a significant environmental problem because of its high water and organic matter contents. However, TW should not be considered a residual liquid. It contains a high concentration of valuable components such as oligosaccharides and soluble polysaccharides as sources of carbon also proteins as sources of nitrogen $[12,13]$. Tofu whey has high levels of the protein so that it can be used as a source of nitrogen to support the growth of microorganisms. Thus, the tofu whey is potential as a substrate to produce biohydrogen. Several studies on biohydrogen production using TW as a substrate have been carried out. The research conducted by Kim and Lee [14], obtained a hydrogen yield (HY) $2.3 \mathrm{~mol} \mathrm{H}_{2} / \mathrm{mol}$ equivalent of glucose using TW that has been treated with a pH of 5.5. Then, the research of Lay et al. [15] obtained an HY 107.5
$\mathrm{mL}-\mathrm{H}_{2} / \mathrm{g}$ COD with a temperature of fermentation at $35^{\circ} \mathrm{C}$ and TW concentrations $20 \mathrm{~g}-\mathrm{COD} / \mathrm{L}$ with a treated $\mathrm{pH} 5.5-$ 6.0 using a batch system.

Biohydrogen production is strongly influenced by the content of carbon and nitrogen substrates, hydrogenproducing bacteria, and bioprocess engineering during fermentation. Therefore, further studies are needed on biohydrogen production to produce the maximum yield and productivity. Due to very high COD levels in vinasse and high nitrogen levels in TW, vinasse, and TW can be combined as a media substrate to produce biohydrogen. Vinasse can be used as a carbon source, and TW is used as a nitrogen source for $R$. marinum to grow and produce biohydrogen. This research aims to find an optimum COD/N ratio of the substrate to obtain the highest volume and productivity of hydrogen gas production by $R$. marinum on vinasse and TW substrate.

\section{MATERIAL AND METHOD}

\section{A. Microorganism and Media}

The microorganisms used in this research were Rhodobium marinum. $R$. marinum stock culture was obtained from NBRC (NITE Biological Resource Center) with the collection number 100434. Substrates used in this research were vinasse obtained from PT. Madu Kismo, Yogyakarta, Indonesia, and tofu whey obtained from the tofu industry in Dramaga, Bogor, Indonesia.

\section{B. Characterization of Vinasse and TW}

Characterization vinasse and TW were conducted by measuring the Chemical Oxygen Demand (COD) following SNI method, Total Nitrogen and Total Organic Acids were analyzed following AOAC method and $\mathrm{pH}$ were examined using pH meter (Jenway 3505).

\section{Pretreatment of Vinasse and TW}

Pretreatment was done in various stages of treatment, such as by filtration, adjusted $\mathrm{pH} 8$ using $10 \mathrm{~N} \mathrm{NaOH}$ and sterilization by autoclaving (121 C in 15 minutes).

\section{Biohydrogen Production in Substrates Combination Vinasse and $T W$}

Biohydrogen production was conducted by using a variation of COD concentration of vinasse and Nitrogen concentration of TW. In this research variation of COD/N used were $10,000 / 1 ; 20,000 / 1 ; 30,000 / 1 ; 40,000 / 1 ; 50,000 / 1$. Photofermentation was performed using Scott bottles of 120 $\mathrm{mL}$, with a working volume of substrate $80 \mathrm{~mL}$. R. marinum (optical density \pm 0.2 ) was inoculated into a pre-treated substrate. After inoculation, the substrate bottles were placed on a shaker at $120 \mathrm{rpm}$ and irradiating fluorescent lamp (tubular lamp, Philips) $60 \mathrm{watt} / \mathrm{m}^{2}$ at room temperature $\left(30^{\circ} \mathrm{C}\right)$. Fermentation was carried out for 3,6 and 9 days.

\section{E. Analytical Methods}

Hydrogen gas was determined by Gas Chromatography using a thermal conductivity detector (TDC) with Porapak column. The oven temperature was set at $250^{\circ} \mathrm{C}$ and $150{ }^{\circ} \mathrm{C}$ respectively. The flow rate of carrier gas was used as a standard. Calculations for the composition of gases were accomplished using a comparison area between samples and 
standard. COD assays were determined according to SNI method. Total organic acid and total nitrogen assays were analyzed according to AOAC [16].

\section{RESULTS AND DISCUSSION}

\section{A. Characterization of Vinasse and Tofu Whey}

Characterization results of vinasse and TW are presented in Table 1. The results show that vinasse has higher COD levels and organic acids than TW, while the nitrogen content is more prevalent on TW than in vinasse. Vinasse has high COD levels $(58,433 \mathrm{mg} / \mathrm{L})$, and vinasse contains very high organic and non-organic material. Reis et al. [17] research the vinasse's COD content is $42,818 \mathrm{mg} / \mathrm{L}$. In general, vinasse has a low $\mathrm{pH}$, a blackish-brown color that contains many residues, organic and inorganic components. Phenolic components (such as humic acid and tannic acid), melanoidin (the result of a reaction between sugars and proteins by Maillard reaction), caramel, and furfural components contribute to the color of vinasse. Some of these components which cause vinasse complex and challenging to be degraded. According to Ramos Ibarra et al. [18], the tequila vinasse's COD content, namely $22,085 \pm 1325 \mathrm{mg} / \mathrm{L}$. The organic load is mainly composed of carbohydrates (7.4 $\mathrm{g} / \mathrm{L})$ total sugars, lactate $(4.7 \mathrm{~g} / \mathrm{L})$ and the other short-chain organic acids (2.6 g/L). The previous study [19] showed the COD content of tequila vinasse, namely $63.1 \pm 6.5 \mathrm{~g} / \mathrm{L}$, and total nitrogen is $220 \pm 63.6 \mathrm{mg} / \mathrm{L}$. Vinasse is an effluent generated during the production of alcohol in the wine distillation process. This effluent can be highly damaging in the areas in which it is discarded due to its high organic load, low $\mathrm{pH}$, and high corrosivity [20].

TABLE I

CHARACTERIZATION OF VINASSE AND TW

\begin{tabular}{|l|l|l|l|}
\hline \multicolumn{1}{|c|}{$\begin{array}{c}\text { Testing } \\
\text { Parameters }\end{array}$} & \multicolumn{1}{|c|}{ Vinasse } & \multicolumn{1}{|c|}{ TW } & \multicolumn{1}{|c|}{ Unit } \\
\hline COD & 58,433 & 5199.88 & $\mathrm{mg} / \mathrm{L}$ \\
\hline Total Nitrogen & 83.10 & 149.20 & $\mathrm{mg} / \mathrm{L}$ \\
\hline Total Organic Acids & 11.15 & 2.79 & $\%$ \\
\hline $\mathrm{pH}$ & 3.63 & 4.57 & - \\
\hline
\end{tabular}

TW is liquid waste from coagulation in making tofu, and it has a high nitrogen content. The high nitrogen content is produced from soluble protein from soybeans. Laboratory result shows that the levels of nitrogen TW were taken from a factory in Dramaga is higher $(149.20 \mathrm{mg} / \mathrm{L})$ compared to vinasse, but organic acids and COD levels of TW are lower when compared to vinasse. This result is likely due to the raw material of sugarcane vinasse contains more carbon than nitrogen. Otherwise, in Lay et al. [15], the study reported that the COD content from tofu processing wastewater, namely $36.4 \mathrm{~g} / \mathrm{L}$, total carbohydrates $12.8 \mathrm{~g} / \mathrm{L}$, and protein $1.9 \mathrm{~g} / \mathrm{L}$. Martinez et al. [21] and Zhao et al. [22] revealed that a large amount of liquid by-product called tofu whey is produced during tofu manufacturing. Whey is reported to contain a high content of valuable nutrients, including protein (source of nitrogen to support the growth of microorganisms), oligosaccharides (source of carbon), and isoflavones.

\section{B. Biohydrogen Production in Substrates Combination Vinasse and TW}

The results of biohydrogen production from substrates combination of vinasse and TW with various COD/N ratios on the third, sixth, and ninth day are shown in Table 2 and Fig 1. The highest volume of hydrogen and HPR were achieved at a COD/ $\mathrm{N}$ ratio of $40,000 / 1$ on a ninth day, namely $95.72 \pm 6.51 \mathrm{~mL} \mathrm{H}_{2} / \mathrm{L}$ and $121.44 \mathrm{~mL} \mathrm{H}_{2} / \mathrm{L} / \mathrm{d}$, respectively. The lowest volume of hydrogen and HPR were found at a $\mathrm{COD} / \mathrm{N}$ ratio of $10,000 / 1$ on day 9th, i.e. $6.72 \pm 8.22 \mathrm{~mL} \mathrm{H}_{2} / \mathrm{L}$ and $6.14 \mathrm{~mL} \mathrm{H}_{2} / \mathrm{L} / \mathrm{d}$, respectively. All these ratios can produce biohydrogen gas but by different amounts. They can also generate biohydrogen from the third day until the ninth day. At a ratio of 20,000/1 to 50,000/1, biohydrogen is increased from the third day until the ninth day. Except at a ratio of $10,000 / 1$, bio-hydrogen has decreased (Fig. 1). According to Buitrón and Carvajal [23], the concentration of the Vinasse substrate has two effects on bio-hydrogen production, namely (a) the concentration of the substrate is likely to be a barrier, and (b) there is some concentration to maximize bio-hydrogen production. The previous studies [24] reported that the high production of bio-hydrogen obtained at high substrate concentration might be explained by the fact that organic acids' levels increased as the substrate concentration increased. According to Park et al. [25], organic acids were increased at higher substrate loads.

At COD/ $\mathrm{N}$ ratio of $10,000 / 1$, hydrogen gas is a decline from the third day until the ninth day (Fig. 1). Whereas in the other ratios, hydrogen gas increase from the third day until the ninth day. This result is presumably because the carbon source has been exhausted on the third day, so all that remains is toxic substances contained in waste. Thus, gas production declines after the $3^{\text {rd }}$ day. Also, the declining production of biohydrogen in a $10,000 / 1 \mathrm{mg} / \mathrm{L}$ ratio is thought because the toxic compounds are formed when the fermentation process or the presence of propionic acid. In the low concentration of substrate affecting propionic acid production, propionic acid can inhibit biohydrogen production. According to Lazaro et al. [26], a barrier in biohydrogen production using vinasse is the accumulation of organic acids produced when the process takes place and their toxic components in vinasse as phenolic components and furfural. Also, it can be influenced by differences in COD concentration that affect metabolic pathways that are formed at each concentration. The research indicated the existence of different metabolic pathways that are prominent in every different vinasse concentration so that the results of the production of each concentration also vary. A low concentration of vinasse can affect the production of propionic acid. Furthermore, hydrogen gas is not produced if the by-product is lactic acid and propionic acid [27]. 


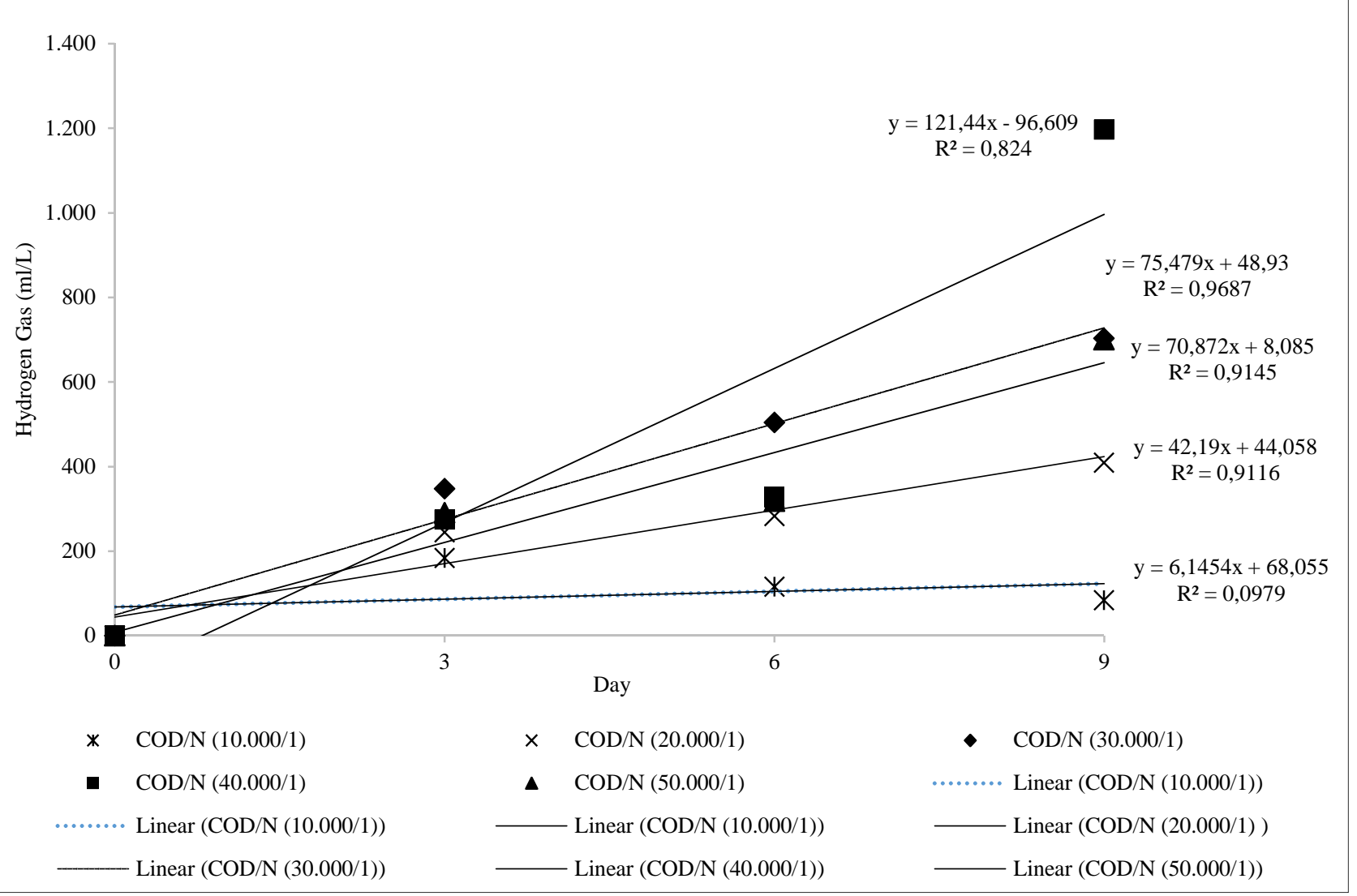

Fig. 1 Linear Regression of Hydrogen Gas Ratio 10000/1 to 50000/1 mg/L

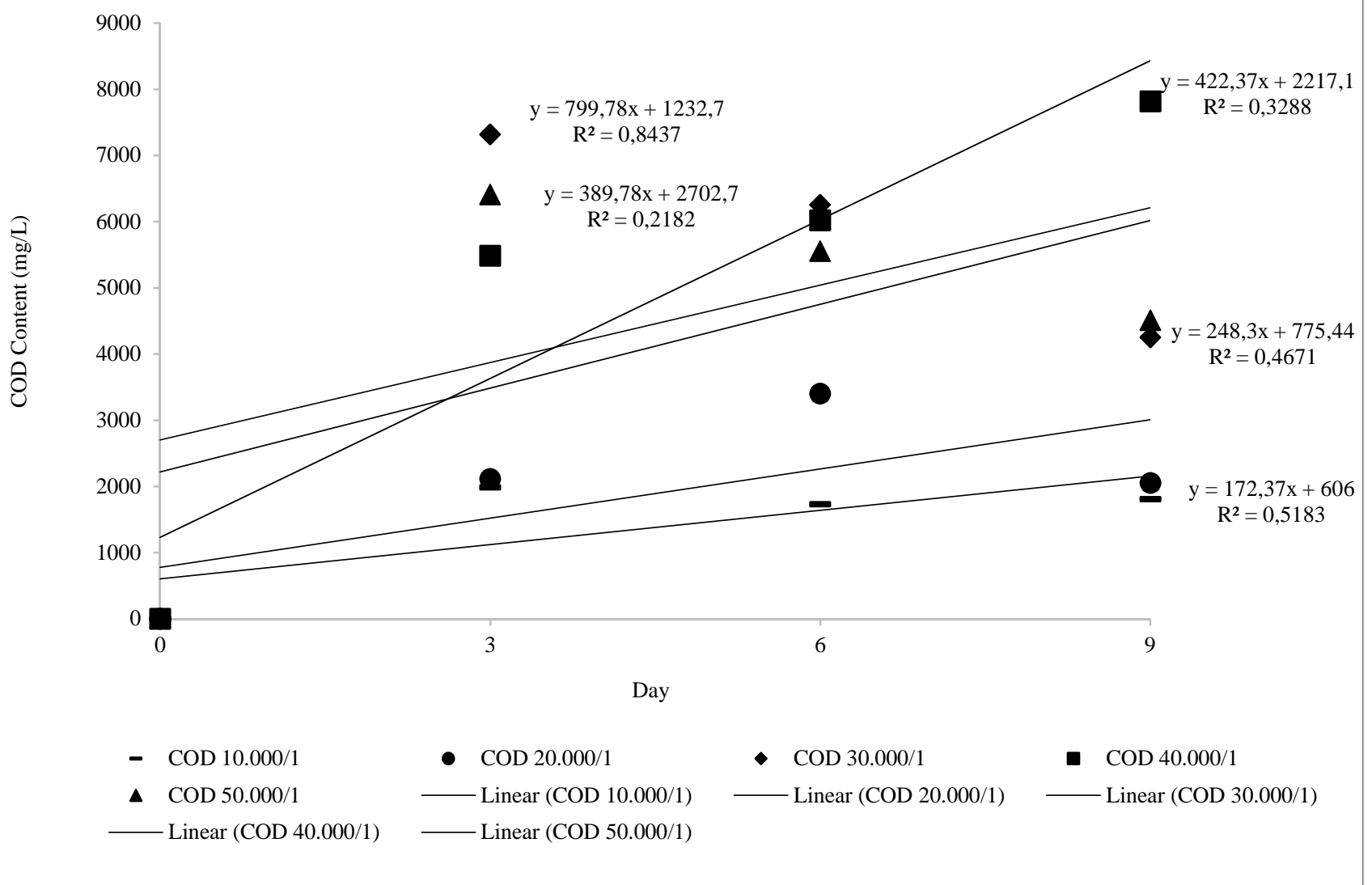

Fig. 2 Linear Regression of Cod Removal Ratio 10000/1 To 50000/1 mg/L 
TABLE II

RESUlts OF BIOHYDROGEN GAS PRODUCTION AT THE COD/N RATIO 10,000/1-50,000/1

\begin{tabular}{|c|c|c|c|c|c|}
\hline COD/N Ratio (mg/L) & Days & $\begin{array}{c}\text { Hydrogen Gas } \\
\left(\mathbf{m L} \mathbf{H}_{\mathbf{2}} / \mathbf{L}\right)\end{array}$ & $\begin{array}{c}\text { HPR (mL } \\
\left.\mathbf{H}_{\mathbf{2}} / \mathbf{L} / \mathbf{d}\right)\end{array}$ & COD Removal (mg/L) & $\begin{array}{c}\text { COD Removal Rate (mg } \\
\text { COD/L/d) }\end{array}$ \\
\hline $10.000 / 1$ & 3 & $14.67 \pm 3.69$ & 6.14 & $1986.66 \pm 235.7$ & 172.37 \\
\hline & 6 & $9.23 \pm 1.71$ & & $1731.12 \pm 7.8$ & \\
\hline & 9 & $6.72 \pm 8.22$ & & $2114.44 \pm 345.6$ & 248.29 \\
\hline & 3 & $19.52 \pm 3.99$ & 42.19 & $3403.33 \pm 365.3$ & \\
\hline & 6 & $22.59 \pm 5.16$ & & $2053.34 \pm 200.3$ & \\
\hline & 9 & $32.72 \pm 1.45$ & & $7320.00 \pm 612.8$ & 389.77 \\
\hline & 3 & $27.82 \pm 1.87$ & 75.47 & $6253.33 \pm 329.9$ & \\
\hline & 6 & $40.30 \pm 1.72$ & & $4253.33 \pm 141.4$ & \\
\hline & 9 & $56.22 \pm 3.07$ & & $5486.67 \pm 282.8$ & \\
\hline & 3 & $21.97 \pm 1.01$ & 121.44 & $6020.00 \pm 542.1$ & 799.77 \\
\hline & 6 & $26.25 \pm 3.87$ & & $7820.00 \pm 400.6$ & \\
\hline & 9 & $95.72 \pm 6.51$ & & $6408.88 \pm 408.5$ & \\
\hline & 3 & $23.24 \pm 0.53$ & 70.87 & $5553.33 \pm 157.1$ & 422.37 \\
\hline
\end{tabular}

Eventually, hydrogen-producing bacteria may show low metabolic activity at shallow substrate concentrations, as a result of that, decreasing the potential of biohydrogen production [28].

Theoretically, the more substrate concentration is given, the more biohydrogen gas is also produced. However, in this research, the highest HPR and hydrogen gas achieved at ratio 40,000/1. This result is because the toxic concentrations that contained in vinasse and TW at a ratio of 50,000/1 is very high, so that $R$. marinum cannot produce biohydrogen gas to the maximum. Whereas, in the ratio of $40,000 / 1, R$. marinum can still tolerate toxic amounts contained and optimally utilize the substrate so that it can produce biohydrogen gas higher than the ratio of 50,000/1. The more of COD concentration of vinasse is added to media production, the more toxic components also contained in there so that it can inhibit biohydrogen production. Elbeshbishy et al. [28] found the high concentrations of a substrate may lead to inhibition of biohydrogen production due to organic overloading, presence of a toxic substance, accumulation of organic acids, acidification of intracellular $\mathrm{pH}$, and highpressure biohydrogen partial. The phenolic compounds, melanoidins and organic acids contained vinasse could impact toxicity to the microorganism. Lazaro et al. [26] found that the presence of toxic compounds on vinasse, such as phenolic and furfural can affect bacteria's capability to produce hydrogen.

Also, nitrogen that converted to ammonia in the high concentrations can inhibit production (Table 2). According to Sung [29], a protein in the substrate decomposed at fermentation and produces ammonia/ammonium. The bacteria involved in the production of biogas using ammonia/ammonium as the nitrogen source. However, in high concentrations, the compound can be a barrier or toxic to bacteria growth. Furthermore, Soubes et al. [30] reported that if too little nitrogen in a substrate, then the bacteria will not synthesize carbon-containing substrates. Also, if the nitrogen levels are excessive in the substrate, it will be released in the form of ammonia so that the bacterial growth will be slower. Chen et al. [31] reported that nitrogenases are more likely to reduce nitrogen to ammonia. Kapdan and Kargi [1] also revealed in the process of forming hydrogen gas, the work of nitrogenase enzyme can also be inhibited by excessive ammonia, ammonium, and a high ratio of carbon and nitrogen $(\mathrm{C} / \mathrm{N})$.

Biohydrogen production with a combination of vinasse and TW is promising to be used as a medium of biohydrogen gas production. Junior et al. [32] who produced biohydrogen from vinasse substrate with Clostridium bacteria and Pectinatus using a pack bed reactor with a working volume of $2.3 \mathrm{~L}$ obtained HPR $509.5 \mathrm{~mL}-\mathrm{H}_{2}$.d-1.L-1. Buitron et al. [33] obtained HPR $57.4 \mathrm{~mL} \mathrm{H} / \mathrm{L}-\mathrm{h}$ using tequila vinasse as a substrate and pre-treated anaerobic sludge as an inoculum to produce biohydrogen. Lamaison et al. [34] obtained HPR 8.4 and $9.5 \mathrm{mmol} / \mathrm{L} / \mathrm{d}$ using the thermophilic biohydrogen production method by mixed culture microorganism in pretreated sludge of sugarcane vinasse with afforded heat $\left(80^{\circ} \mathrm{C}\right.$ for $15 \mathrm{~min}$ ) or acid ( $\mathrm{pH} 3$ for $24 \mathrm{~h}$ ). The research of Buitron and Carvajal. [23], a maximum volumetric hydrogen production rate of $50.5 \mathrm{~mL} \mathrm{H} / 2 / \mathrm{L}$ were obtained when the reactor was fed with $3 \mathrm{~g} \mathrm{COD} / \mathrm{L}$ tequila vinasse at $35^{\circ} \mathrm{C}$ and $12 \mathrm{~h}$ HRT. The best hydrogen production rate was 0.57 $\mathrm{L} / \mathrm{h} / \mathrm{L}$ at HRT $1 \mathrm{~h}$, and concentration substrate $100 \%$ vinasse [17]. Tena et al. [20] reported that the maximum hydrogen production rate obtained with the acidogenic inoculum and sludge thermal inoculum reached the peak after three days and amounted to $11 \mathrm{~mL} \mathrm{H}_{2} /\left(\mathrm{gVS}_{\text {added }} \mathrm{d}\right)$ and $20 \mathrm{~mL}$ $\mathrm{H}_{2} /\left(\mathrm{gVS}_{\text {added }} \mathrm{d}\right)$, respectively. 
TABLE III

EFFICIENCY AND CHEMICAL PROPERTIES OF SUBSTRATE AFTER PRODUCTION

\begin{tabular}{|c|c|c|c|c|c|}
\hline $\begin{array}{l}\text { COD Content } \\
(\mathrm{mg} / \mathrm{l})\end{array}$ & Days & Substrate Efficiency (\%) & $\begin{array}{c}\text { Total Organic Acid } \\
(\%)\end{array}$ & $\begin{array}{c}\text { Total Nitrogen } \\
(\mathrm{mg} / \mathrm{L})\end{array}$ & pH \\
\hline \multirow[t]{3}{*}{$10.000 / 1$} & 3 & 21,98 & 0.07 & 2.14 & 6.05 \\
\hline & 6 & 19,15 & 0.15 & 3.25 & 6.15 \\
\hline & 9 & 20,01 & 0.16 & 10.9 & 6.19 \\
\hline \multirow[t]{3}{*}{$20.000 / 1$} & 3 & 11,45 & 0.12 & 3.25 & 5.96 \\
\hline & 6 & 18,44 & 0.06 & 3.07 & 6.10 \\
\hline & 9 & 10,95 & 0.16 & 3.79 & 6.00 \\
\hline \multirow[t]{3}{*}{$30.000 / 1$} & 3 & 23,33 & 0.10 & 5.64 & 5.90 \\
\hline & 6 & 19,93 & 0.09 & 5,12 & 5.97 \\
\hline & 9 & 13,94 & 0.11 & 7,17 & 5.91 \\
\hline \multirow[t]{3}{*}{$40.000 / 1$} & 3 & 14,65 & 0.29 & 8.88 & 5.66 \\
\hline & 6 & 15,44 & 0.21 & 6.83 & 5.83 \\
\hline & 9 & 20,06 & 0.11 & 9.22 & 5.83 \\
\hline \multirow[t]{3}{*}{$50.000 / 1$} & 3 & 15,24 & 0.33 & 9.74 & 5.67 \\
\hline & 6 & 12,88 & 0.39 & 8.88 & 5.81 \\
\hline & 9 & 10,72 & 0.19 & 10.6 & 5.91 \\
\hline
\end{tabular}

Kim et al. [35] used pre-treated tofu-making process waste by adding $1 \% \mathrm{HCL}$, adjusting temperature $35^{\circ} \mathrm{C}$ and $\mathrm{pH}$ at 7 and using anaerobic microflora consortium, produced a maximum biohydrogen gas $1.48 \mathrm{~mol} \mathrm{H}_{2} / \mathrm{mol}$ Hexose $_{\text {added. }}$ Furthermore, Kim et al. [36] also used pretreated tofu-making process waste with $0.5 \% \mathrm{HCL}$ adjusting temperature $60^{\circ} \mathrm{C}$ and $\mathrm{pH} 5.5$ and using anaerobic microflora consortium produced a maximum biohydrogen gas $1.20 \mathrm{~mol}$

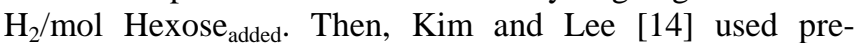
treated tofu process waste by heating $110^{\circ} \mathrm{C}$ for 30 minutes using anaerobic inoculum in a CSTR type reactor, produced biohydrogen gas $2.3 \mathrm{~mol} \mathrm{H}_{2} \mathrm{~mol} / \mathrm{mol}$ glucose.

\section{Substrate Efficiency and COD Removal Rate}

The efficiency of substrate and COD removal rate from all ratios can be seen in Table 2, 3 and Fig. 2. The highest efficiency of substrate achieved at a ratio of $30,000 / 1$ on the third day by $23.33 \%$. The lowest is obtained at a ratio of $50,000 / 1$ by $10.72 \%$. The highest COD removal rate is achieved at a ratio of $40,000 / 1$, and the lowest is obtained $10,000 / 1$. From the results of COD Removal and COD Removal Rate (Fig 2), it can be concluded that the consumption of COD by $R$. marinum was not optimal, this is presumably due to the existence of toxic compounds in the vinasse. According to Lazaro et al. [26], the presence of toxic compounds such as phenolic compounds and furfural in vinasse may affect bacteria's capability to produce hydrogen. Tena et al. [20] reported that soluble COD removal was lower than $23 \%$ in all tests. Yang and Wang [37] also reported that soluble COD concentration decreased, with significant reductions in removal rates of 7.1-31.3\%.

Although the COD removal rate at a ratio of $10.000 / 1$ is the lowest, the substrate's efficiency is relatively high $(19.15-21.98 \%)$. At the $\mathrm{COD} / \mathrm{N}$ ratio of $40,000 / 1$, the substrate's value of efficiency is also high by $20.06 \%$. Although the highest efficiency of the substrate at the ratio of 30,000/1, but the highest COD removal rate is gained by the ratio of $40,000 / 1$ by $799.77 \mathrm{mg} \mathrm{COD} / \mathrm{L} / \mathrm{d}$ (Fig. 2), because at the ratio of 40,000/1, the value of COD Removal is high from the third day to ninth day (Fig. 2). It is directly proportional to the highest hydrogen gas and HPR that is also produced in the ratio of 40,000/1. The more COD concentration used by $R$. marinum, the more bio-hydrogen gas produced, so the value of COD removal rate is getting higher. Torquato et al. [38] obtained a maximum removal rate of $41 \%$ in vinasse digestion to produce hydrogen. However, Silva et al. [39,40] revealed that COD removal of the substrate was lower than $20 \%$ when trying the codigestion of food waste, sewage sludge and crude glycerol.

\section{CONCLUSION}

Several conclusions were drawn from our research on biohydrogen production in substrates combination of vinasse and tofu whey using Rhodobium marinum. Vinasse has higher Chemical Oxygen Demand $(58,433 \mathrm{mg} / \mathrm{L})$ than tofu whey. However, tofu whey has higher nitrogen content than vinasse $(149.20 \mathrm{mg} / \mathrm{L})$. The combination of both liquid wastes is a suitable substrate as sources of carbon and nitrogen for hydrogen gas production using Rhodobium marinum. The optimum ratio of $\mathrm{COD} / \mathrm{N}$ was achieved at the ratio of 40,000/1 mg/L. The highest hydrogen gas, HPR and COD removal rate were achieved at the $\mathrm{COD} / \mathrm{N}$ ratio of $40,000 / 1$ on the $9^{\text {th }}$ day, amounted to $95.72 \pm 6.51 \mathrm{~mL} \mathrm{H}_{2} / \mathrm{L}$, $121.44 \mathrm{~mL} \mathrm{H} / 2 / \mathrm{d}$ and $799.77 \mathrm{mg} \mathrm{COD} / \mathrm{L} / \mathrm{d}$, respectively. The combination of vinasse and TW are potential to produce biohydrogen gas.

\section{ACKNOWLEDGMENT}

This research was supported by the Competitive Research Grant Program 2015-2016 from the Indonesian Institute of Sciences.

\section{REFERENCES}

[1] I. K. Kapdan and F. Kargi, "Bio-hydrogen production from waste materials," Enzyme Microb. Technol., vol. 38, no. 5, pp. 569-582, 2006 . 
[2] M. M. Arimi, J. Knodel, A. Kiprop, S. S. Namango, Y. Zhang, and S U. Geißen, "Strategies for improvement of biohydrogen production from organic-rich wastewater: A review," Biomass and Bioenergy, vol. 75, no. 0 , pp. 101-118, 2015.

[3] A. Ghimire et al., "A review on dark fermentative biohydrogen production from organic biomass: Process parameters and use of byproducts," Appl. Energy, vol. 144, pp. 73-95, 2015.

[4] D. Das and T. N. Veziroglu, "Advances in biological hydrogen production processes," Int. J. Hydrogen Energy, vol. 33, no. 21, pp. 6046-6057, 2008.

[5] J. B. Veeramalini, I. A. Ebenezer, S. Park, and J. Jayamuthunagai, "Bioresource Technology Continuous production of biohydrogen from brewery e ffl uent using co- culture of mutated Rhodobacter M 19 and Enterobacter aerogenes," Bioresour. Technol., vol. 286, no. March, p. 121402, 2019.

[6] O. García-depraect, I. Valdez-vázquez, E. R. Rene, J. Gómez-romero, A. López-lópez, and E. León-becerril, "Lactate- and acetate-based biohydrogen production through dark co-fermentation of tequila vinasse and nixtamalization wastewater: Metabolic and microbial community dynamics," Bioresour. Technol., 2019.

[7] J. R. Banu, "Industrial Wastewater to Biohydrogen: Possibilities towards successful biorefinery Corresponding Author:" 2019.

[8] I. Syaichurrozi, Budiyono, and S. Sumardiono, "Predicting kinetic model of biogas production and biodegradability organic materials: Biogas production from vinasse at variation of $\mathrm{COD} / \mathrm{N}$ ratio,' Bioresour. Technol., vol. 149, pp. 390-397, 2013.

[9] T. Nandy, S. Shastry, and S. N. Kaul, "Wastewater management in a cane molasses distillery involving bioresource recovery," 2002

[10] D. Pant and A. Adholeya, "Biological approaches for treatment of distillery wastewater: A review," vol. 98, pp. 2321-2334, 2007.

[11] G. Vaccari, E. Tamburini, G. Sgualdino, K. Urbaniec, and J. Klemeš, "Overview of the environmental problems in beet sugar processing: Possible solutions," J. Clean. Prod., vol. 13, no. 5 SPEC. ISS., pp. 499-507, 2005.

[12] J. Chua and S. Liu, "Trends in Food Science \& Technology Soy whey: More than just wastewater from tofu and soy protein isolate industry," Trends Food Sci. Technol., vol. 91, no. June, pp. 24-32, 2019.

[13] J. S. Henao, J. R. Wagner, and G. G. Palazolo, "In fl uence of chemical composition and structural properties on the surface behavior and foam properties of tofu-whey concentrates in acid medium," vol. 128, no. October 2019, 2020.

[14] M. Kim and D. Lee, "Bioresource Technology Fermentative hydrogen production from tofu-processing waste and anaerobic digester sludge using microbial consortium," Bioresour. Technol., vol. 101, no. 1, pp. S48-S52, 2010.

[15] C. Lay, B. Sen, S. Huang, C. Chen, and C. Lin, "Sustainable bioenergy production from tofu-processing wastewater by anaerobic hydrogen fermentation for onsite energy recovery," vol. 58, pp. 6067, 2013.

[16] K. Anam, M. S. Habibi, T. U. Harwati, and D. Susilaningsih, "Photofermentative hydrogen production using Rhodobium marinum from bagasse and soy sauce wastewater," Int. J. Hydrogen Energy, vol. 37 , no. 20 , pp. $15436-15442,2012$

[17] C. M. Dos Reis, M. F. Carosia, I. K. Sakamoto, M. B. Amâncio Varesche, and E. L. Silva, "Evaluation of hydrogen and methane production from sugarcane vinasse in an anaerobic fluidized bed reactor," Int. J. Hydrogen Energy, vol. 40, no. 27, pp. 8498-8509, 2015

[18] R. Ramos-ibarra, R. Garcı, G. Guatemala-morales, E. Arriolaguevara, and G. Toriz-gonz, "ScienceDirect Photofermentation of tequila vinasses by Rhodopseudomonas pseudopalustris to produce hydrogen," pp. 1-13, 2018.

[19] O. García-depraect and E. León-becerril, "Fermentative biohydrogen production from tequila vinasse via the lactate- acetate pathway: Operational performance, kinetic analysis and microbial ecology,' Fuel, vol. 234, no. June, pp. 151-160, 2018

[20] M. Tena and R. Solera, "E ff ects of several inocula on the biochemical hydrogen potential of sludge- vinasse co-digestion," vol. 258, no. July, 2019.

[21] M. Corzo-martinez, G. García-campos, A. Montilla, and F. J. Moreno, "Tofu whey permeate is an efficient source to enzymatically produce prebiotic fructooligosaccharides and novel fructosylated \# galactosides," 2016

[22] C. Zhao, P. Kim, and J. Eun, "LWT - Food Science and Technology In $\mathrm{fl}$ uence of high-intensity ultrasound application on the physicochemical properties, iso fl avone composition, and antioxidant activity of tofu whey," vol. 117, no. August 2019, 2020.

[23] G. Buitrón and C. Carvajal, "Biohydrogen production from Tequila vinasses in an anaerobic sequencing batch reactor: Effect of initial substrate concentration, temperature and hydraulic retention time,' Bioresour. Technol., vol. 101, no. 23, pp. 9071-9077, 2010.

[24] O. García-depraect, E. R. Rene, and V. F. Diaz-cruces, "Department of Environmental Technology, Centro de Investigación y Asistencia en Department of Environmental Engineering and Water Technology, UNESCO-IHE Corresponding author:” Bioresour. Technol., 2018.

[25] J. Park, D. Kim, S. Kim, J. Yoon, and H. Park, "ScienceDirect Effect of substrate concentration on the competition between Clostridium and Lactobacillus during biohydrogen production," Int. J. Hydrogen Energy, pp. 1-10, 2017.

[26] C. Z. Lazaro, V. Perna, C. Etchebehere, and M. B. A. Varesche, "Sugarcane vinasse as substrate for fermentative hydrogen production: The effects of temperature and substrate concentration,' Int. J. Hydrogen Energy, vol. 39, no. 12, pp. 6407-6418, 2014.

[27] D. H. Kim, S. H. Kim, I. B. Ko, C. Y. Lee, and H. S. Shin, "Start-up strategy for continuous fermentative hydrogen production: Early switchover from batch to continuous operation," Int. J. Hydrogen Energy, vol. 33, no. 5, pp. 1532-1541, 2008

[28] E. Elbeshbishy, B. R. Dhar, G. Nakhla, and H. Lee, "A critical review on inhibition of dark biohydrogen fermentation," Renew. Sustain. Energy Rev., vol. 79, no. May, pp. 656-668, 2017

[29] S. Sung, "Ammonia inhibition on thermophilic anaerobic digestion," vol. 53, pp. 43-52, 2003.

[30] M. Soubes, L. Muxf, A. Fernandez, and S. Tarlera, "Volume 16 No 2 (February 1994) pp. 195-200 Received 5th January," vol. 16, no. 2 pp. 195-200, 1994.

[31] X. Chen, Y. Sun, Z. Xiu, X. Li, and D. Zhang, "Stoichiometric analysis of biological hydrogen production by fermentative bacteria,' vol. 31, pp. 539-549, 2006.

[32] A. D. N. Ferraz Júnior, C. Etchebehere, and M. Zaiat, "Mesophilic hydrogen production in acidogenic packed-bed reactors (APBR) using raw sugarcane vinasse as substrate: Influence of support materials," Anaerobe, vol. 34, pp. 94-105, 2015.

[33] G. Buitrón, G. Kumar, A. Martinez-Arce, and G. Moreno, "Hydrogen and methane production via a two-stage processes (H2-SBR + $\mathrm{CH} 4-$ UASB) using tequila vinasses," Int. J. Hydrogen Energy, vol. 39, no. 33, pp. 19249-19255, 2014

[34] F. Do Carmo Lamaison, P. A. M. De Andrade, A. D. Bigaton, F. D. Andreote, R. V. Antônio, and V. Reginatto, "Long-term effect of acid and heat pretreatment of sludge from a sugarcane vinasse treatment plant on the microbial community and on thermophilic biohydrogen production," Int. J. Hydrogen Energy, vol. 40, no. 41, pp. 14124 14133, 2015.

[35] D. Kim, D. Lee, and M. Kim, "Enhanced biohydrogen production from tofu residue by acid / base pretreatment and sewage sludge addition," Int. J. Hydrogen Energy, vol. 36, no. 21, pp. 13922-13927, 2011

[36] M. Kim, D. Lee, and D. Kim, "Continuous hydrogen production from tofu processing waste using anaerobic mixed microflora under thermophilic conditions," Int. J. Hydrogen Energy, vol. 36, no. 14, pp. 8712-8718, 2010

[37] G. Yang and J. Wang, "Co-fermentation of sewage sludge with ryegrass for enhancing hydrogen production: Performance evaluation and kinetic analysis," Bioresour. Technol., 2017.

[38] L. D. M. Torquato et al., "Potential of biohydrogen production from effluents of citrus processing industry using anaerobic bacteria from sewage sludge," Waste Manag., 2016.

[39] M. S. Silva, L. B. Oliveira, and C. F. Mahler, "ScienceDirect Hydrogen production through anaerobic co-digestion of food waste and crude glycerol at mesophilic conditions," pp. 1-10, 2017.

[40] F. M. S. Silva, C. F. Mahler, L. B. Oliveira, and J. P. Bassin, "Hydrogen and methane production in a two-stage anaerobic digestion system by co-digestion of food waste, sewage sludge and glycerol," 2018 